\title{
On Literary Criticism and Literary Critics
}

\author{
Fuhua Liu \\ School of Foreign Languages, Dalian Jiaotong University, Dalian, Liaoning 116028, China
}

Keywords: literary criticism, literary creation, literary critics

Abstract: The present paper discusses the functions of literary criticism, the intertextuality between literary criticism and literary creation, and the qualities a qualified literary critic should possess. Through detailed analysis, readers get a better understanding about literary criticism.

\section{Introduction}

In today's literary world, classic literary works rarely come out, while literary critical works in all forms and at all levels explode. Indeed, there is a vivid contrast in terms of number and quality between literary creation and literary criticism, which compels literary critics to ponder on these immortal questions: 1 . What is the significance of literary criticism? 2. What is the relationship between literary creation and literary criticism? 3. How can literary critics effectively criticize literary works? The present paper tries to answer the three questions in the hope of enlightening literary critics in the literary criticism circle.

\section{Body}

\subsection{Functions of Literary Criticism}

Generally speaking, there are two major functions of literary criticism. On the one hand, literary criticism enables readers to better comprehend and appreciate the literary works so that readers' aesthetic awareness can be raised and aesthetic interest can be enhanced. In this way literary criticism helps literary creators to reach the ultimate goal of character perfection and moral cultivation for their readers. As far as I am concerned, we should not deny the social functions of literary works, as literary works are always a reflection of the realistic world the writer lives in. To some extent, it is just the social functions of literary works that make literary criticism appealing and instructive.

On the other, literary criticism should be in a good position to propel writers to create better works. That is, ideally, literary criticism also conversely induces literary works. That is why a large number of writers, especially writers in recent decades, create their literary works with similar themes and writing skills. They all create in the light of a certain literary theory or at least are influenced by an identical literary trend. 


\subsection{The Intertextuality between Literary Criticism and Literary Creation}

The intertextuality between literary creation and literary criticism deserves our special attention. Being the product of literary creation, literary works, especially classic literary works often present the attitudes and views about literature given by the writer. In fact, any responsible literati may consciously or unconsciously reflect on literature itself during his or her creation. For example, in Shakespeare's sonnet 18, the last two lines "So long as men can breathe or eyes can see, So long lives this, and this gives life to thee” show the poet's very confidence about the literary genre---poetry

Throughout literary history home and abroad, it is not difficult for us to discover that many masters of literary creation are also qualified literary critics. For example, there is a war about literature between Lu Xun and Liang Shiqiu. And English romantic poet Wordsworth also has his definition and comprehension of the term "poetry". These masters in English literature alone include Pope, Wordsworth, Keats, Arnold, Yeats and Eliot, just to name a few. Although these masters have not built their independent and systematic modern way of criticism and their critical forms and styles are also varied, they, being literary creators and literary critics as the same time, casually comment in their literary works.

In the modern literary stage, especially in the postmodern literary stage, literary creation is increasingly impacted by the product of literary criticism---literary theories. Of course, social reality influences literary creation. So does literary criticism. Because of the guidance of some revolutionary theories on literature, philosophy and language, similar literary works on an unprecedented scale show up at the same age. The withering of western literature renders critics to reflect on literature itself, starting a new trend of postmodernism. In this age, the integration of literary criticism into literary works has reached an astonishing degree. For example, avant-garde postmodern writer Donald Barthelme creates works that really confuse critics and readers. The latter just cannot tell whether his works are products of literary creation or literary criticism, as his works destructs the literary classics and contain too much accusation of and reflection on literature. Literary criticism in the literary creation like Barthelme's works decreases the readability and aestheticism of literature.

As the same time, literary criticism also develops itself by taking in the essence of literary creation. To begin with, literary criticism will cease to be without literary creation, which is the biggest intertextuality exploitation of literary creation for literary criticism. A creator has his or her own stand, values, aesthetic taste etc. and these qualities held by the creator will be well exploited by the critics, who either support and compliment these qualities or attack them. In addition, literary creation is absolutely subjective, requiring the creators' inspiration and passion. To a large degree, literary criticism inherits the subjective characteristics of literary creation, making the former contain irrational elements that most other disciplines do not possess. The subjective nature in fact lays the foundation of intertextuality between literary creation and literary criticism.

\subsection{Qualities a Qualified Literary Critic Should Possess}

So how to be a qualified literary critic? Unlike literary critics in ancient times, modern literary critics do not have to be literary creators to be eligible. In modern society, independent literary critics come into being, and their work has been professionalized. But the nature of literary criticism decides that literary criticism itself is vastly different from research in the field of science. Even though a literary critic does not necessarily need to be a literary creator as a premise, he or she should at least be hooked on literature, or he or she should at least possess some literary qualities. Professor Deng Xiaomang from Wuhan University even believes that "A literary critic to some extent should also be a literary creator, and he or she should possess the ability to create literary 
works in practice.” [1]

Literary critics do not do their jobs on purpose to meet the needs of readers who refer to their criticism, although they happen to enlighten the readers in one way or another in reality. The main reason for literary critics to criticize is that they are inspired to do so. They criticize on impulse, feeling that it is just unbearable to go without pouring out all their thoughts and feelings after reading a certain piece of literary work. Instead of doing this for an external reason, they do this out of their inner drive. They derive satisfaction from their own comprehension as this is a means of interacting with the writer. In this way, the critic and the creator become bosom friends, with the former deeply appreciating the latter.

Many modern literary critics tend to criticize without reading and fully appreciating the original works, which is often called "intransitive criticism". Wu Yiqin believes the basic principle of literary criticism is to start from studying the original works, but unfortunately most critics in the literary criticism circle just ignore or abandon this golden rule [2]. The first thing a qualified critic should do is to elaborate on the original works. Like a qualified literary creator, a qualified literary critic also needs to be knowledgeable, getting himself or herself familiar with philosophy, politics, architecture, history and many other subjects. To lay a solid foundation for a literary critic's further study, he or she should also have studied all other critics' works.

One way of literary criticism is the general-to-specific analysis of literary works under the guidance of a certain theory. For example, a critic tries to analyze Huang Zhelun's M.Butterfly under Freud's theory. This type of literary criticism is mostly the finding of corresponding details. I am not against this type of literary criticism, but literary critics should really elaborate on the original works. That is, the original works should be the hero in literary criticism. Literary critics should not let theories play the dominant role when criticizing a certain piece of literary work.

As has been mentioned before, literary criticism ideally represents aestheticism the same as literary creation. Virginia Woof's literary criticism is really unique, just like essays, so beautifully and sensibly written that readers of her criticism often benefit more than reading published papers. Form for literary criticism in a sense is not that important, but in the modern society a strict form is required if a literary critic wants to get his or her ideas published. Therefore, due attention should be paid to form, but more attention should be paid to the content and quality of literary criticism. Still, some literary critics hold the mistaken idea that the more they quote from authoritative sources, especially foreign sources, the better their critical products become. Actually, the large amounts of references only indicate the inferiority of their literary criticism. The most important thing for a qualified literary critic is their product's originality. Therefore, although they should collect materials and read extensively, they should be cautious when citing other critics' works. And they should cite only those that are most relevant to the topic they are exploring.

\section{Conclusion}

To summarize, to build a bridge between writers and readers and to help writers create better works are the two major functions of literary criticism. From the perspective of the intertextuality between literary creation and literary criticism, literary creators tend to be good literary critics, and literary works often contain super literary criticism within itself. Likewise, literary criticism develops itself by taking in the essence of literary creation. To be a qualified literary critic, one should possess the necessary literary qualities. To do a good job as a qualified literary critic, one should first study the original works and pay more attention to the content than the form. I hope the essay can shed light on some literary critics in the literary criticism circle. 


\section{References}

[1] Deng Xiaomang. Four Qualities for Literature Critics [J]. Journal of CUPL, 2008 (6): 32-35.

[2] Wu Yiqin. What is Criticism For? ---Two Symptoms of Contemporary Literary Criticism [J]. Literature and Art Studies, 2005 (9): 5-11. 